\title{
Hydrometeorology of the Rajasthan desert rainfall
}

\begin{abstract}
The Western part of the Rajasthan state in India called 'West Rajasthan' is characterized by a desert environment with low and erratic rainfall and sandy soil. This paper deals with some interesting features of rainwater resources in West Rajasthan based on rainfall data of stations for the 124 years (1871-1994) in a manner that the information becomes useful for utilization of its water resources for human activities. The study involves the seasonal features of climate, rainwater of its different districts and of the whole area of West Rajasthan, rainstorms that produced heavy point and areal rainfalls and amount of water generated by them, variability of rainwater that produced droughts and floods in West Rajasthan and evaluation of probable maximum precipitation (PMP). The average annual rainfall of West Rajasthan is $29.5 \mathrm{~cm}$ in 14 rainy days and is the lowest rainfall area in India. The highest and lowest annual total rainfalls in the same period were $72.3 \mathrm{~cm}$ in 1917 and $3.7 \mathrm{~cm}$ in 1918 and the $75 \%$ dependable rainfall is $22.5 \mathrm{~cm}$. Although, rainfall is quite low, widespread flood rainfalls do occur anywhere in West Rajasthan and produce millions of cubic meters of runoff water. The human population in the desert area revealed that about $33 \%$ of the total human population of the Rajasthan state with a density of 114 persons per square kilometer lives in the arid environment of West Rajasthan where the source of fresh water from rainfall is quite low. When looked at densities of 10 to 20 persons in other desert areas of the world, it becomes obvious that West Rajasthan desert area is uniquely populous.
\end{abstract}

Volume 2 Issue $6-2018$

\section{Rakhecha PR}

Former Dy. Director (hydrometeorology), Indian Institute of Tropical Meteorology, Pune, India

Correspondence: Rakhecha PR, Former Dy. Director (hydrometeorology), Indian Institute of Tropical Meteorology, Pune, India, Tel +9l 029l 2639449,

Email rakhachapukhraj@gmail.com

Received: June 27, 2018 | Published: November 23, 2018

Keywords: hydrometeorology, desert, monsoon, depression, rainstorm

\section{Introduction}

There is considerable variation of the climatic features across the state of Rajasthan in India. The state has broadly been divided into three main climatic regions: arid or desert region, semi arid region and sub- humid region on the basis of rainfall. West Rajasthan comprising of the 10 districts of Barmer, Bikaner, Churu, Ganganagar, Jaisalmer, Jalore, Jodhpur, Hanumangarh, Nagaur and Pali with an area of $195091 \mathrm{~km}^{2}$ is characterized by a desert or arid environment of India (Figure 1). It is a part of the Great Indian Desert or Thar Desert that forms a natural boundary between India and Pakistan. Extremely low rainfall with high aridity index, long hot summers with very high temperatures going as high as $50^{\circ} \mathrm{C}$ and cold winters with the temperature as low as $-6^{\circ} \mathrm{C}$, low humidity and high evaporation which is many times the rainfall are some of the noteworthy climaic features of this desert or arid region. Characteristics of the Rajasthan desert have been discussed by many scholars, ${ }^{1-7}$ Compared to other desert regions of the world, West Rajasthan desert is unique in the sense that it comes under the influence of the Indian Southwest monsoon (or summer monsoon) during July and August and occasionally rain producing weather systems like 'lows' and 'depressions' from the Bay of Bengal and the Arabian sea permeate up to parts of Rajasthan and produce heavy rainfall in the desert region. For example, in August, 1973, a severe rainstorm associated with a low pressure area occurred over Rajasthan which caused widespread heavy rainfall over entire Rajasthan during 13 - 19 August. The districts of Jaisalmer, Barmer, Pali \& Jalore in West Rajasthan were marooned for days together. Some stations received in one day rain amounts exceeding their respective mean annual rainfalls. Jaisalmer and Barmer recorded $20 \mathrm{~cm}$ and $23 \mathrm{~cm}$ of rain on 16 and 18 August, 1973 respectively while their annual rainfalls are about $18 \mathrm{~cm}$. and $31 \mathrm{~cm}$ respectively. The total volume of water generated by the storm was estimated at 32293 million cubic meters. ${ }^{8}$ The Meli bund dam was overtopped and breached on $20^{\text {th }}$ August resulting in large loss of life and damage to property. Such instances of heavy rainfall in the desert area are of great importance to formulate new hydrological insights to utilize water in the desert area of Weas Rajasthan. The main purpose of this paper is to present some aspects of hydrometeorology of the Rajasthan desert rainfall useful for improving plant and human life and agriculture.

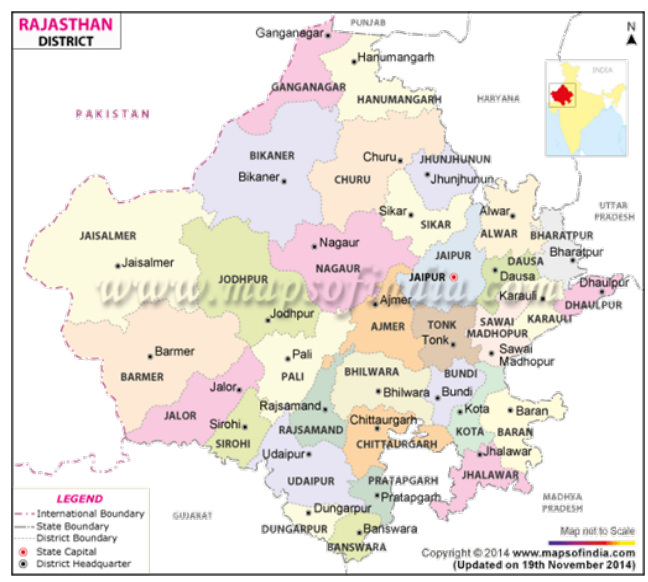

Figure I Map of Rajasthan showing the 10 arid districts of west Rajasthan.

\section{Seasonal features of climate of west Rajasthan}

The dry cold winter and hot summer are the two principal seasons of the West Rajasthan desert when the weather conditions are exactly opposite to one another. Between these two seasons are two transitional periods: the southwest monsoon or rainy period and the post monsoon period. Thus, the year may be divided into four seasons: 
cold winter season (December- February), hot summer season (March- May), southwest monsoon or rainy season (June- September) and Post monsoon season (October- November). The winter season starts from December and continues up to February. It is a season of low temperature and January is the coldest month when at some places the temperature falls below freezing point. Jaisalmer (Figure 1) recorded the lowest temperature of $-5.9^{\circ} \mathrm{C}$ on 12 January 1967. A few rain spells of light to moderate rain occur in winter when extra tropical disturbances called 'Western Disturbances' in meteorological parlance pass over the area through Punjab. The month of March marks the beginning of the hot summer season and continues up to the date of onset of monsoon. Temperatures start rising progressively from March onwards and May and June are the hottest months with the average daily maximum temperatures ranging between $40^{\circ} \mathrm{C}$ and $45^{\circ} \mathrm{C}$ and minimum tempetaures between $24^{\circ} \mathrm{C}$ and $29^{\circ} \mathrm{C}$. The heat during the summer is intense and scorching making West Rajasthan the hottest region in India. The station Ganganagar had recorded a temperature as high as $50^{\circ} \mathrm{C}$ in June 1934 . This is also the period of strong dust raising winds and a blanket of suspended dust covers the whole area and extends to heights of $3 \mathrm{~km}$ or more. Summer season stays for a longer duration than other seasons. Technically monsoon season is the period between the date of onset and date of its withdrawal. The normal date of onset of monsoon over West Rajasthan is about 15 July and starts to withdraw during the first week of September. It stays over West Rajasthan for about 2 months. West Rajasthan receives $90 \%$ of the normal annual rainfall during monsoon season which not only nourishes the rain fed kharif crops but meets the demands of water by the people. The annual rainfall over the West Rajasthan is least in the country. A record of 124 years of annual rainfall for West Rajasthan is presented in Table 1.

\section{Area and population of different districts}

In India a population survey is conducted at an interval of 10 years and is known as decennial survey. Last decennial survey was conducted in 2011. The area, population and the population density of different districts of West Rajasthan based on 2011 survey are given in Table 1. Population density varies from district to district. The population density of West Rajasthan is much less than India's average of 324persons $/ \mathrm{km}^{2}$. This is mainly due to a number of factors such as climatic conditions, fertility of soils, availability of water, means of transportation and communication, growth of trade and infrastructural facilities. The Jaisalmer district occupying $20 \%$ of the area of West Rajasthan has only $3 \%$ of population which is typical of the desert environment. The areas and population are more or less proportionate in other districts. However, it is interesting to note that the West Rajasthan is the most densely populated desert region in the world with a population density of 114 people per $\mathrm{km}^{2}$. About $33 \%$ of the total human population of Rajathan lives in the arid environment of West Rajasthan. The main occupation of the people is agriculture and animal husbandry. The information is useful to determine the total requirement of water for population in each district.

Table 1 Area and population of different districts of west Rajasthan ${ }^{9}$

\begin{tabular}{|c|c|c|c|c|c|c|}
\hline No. & Districts & $\begin{array}{l}\text { Area } \\
\left(\mathrm{km}^{2}\right)\end{array}$ & $\begin{array}{l}\% \text { of total area of arid west } \\
\text { Rajasthan }\end{array}$ & $\begin{array}{l}\text { Population (20 I I } \\
\text { census) }\end{array}$ & $\begin{array}{l}\text { \% of total } \\
\text { population }\end{array}$ & $\begin{array}{l}\text { Density (persons/ } \\
\mathbf{k m}^{2} \text { ) }\end{array}$ \\
\hline 1 & Barmer & 28387 & 15 & $26,04,453$ & 12 & 92 \\
\hline 2 & Bikaner & 27244 & 14 & $23,67,745$ & 11 & 87 \\
\hline 3 & Churu & 16830 & 9 & $20,41,172$ & 9 & 121 \\
\hline 4 & Ganganagar & 7944 & 4 & $19,69,520$ & 9 & 248 \\
\hline 5 & Hanumangarh & 12690 & 7 & $17,79,650$ & 8 & 140 \\
\hline 6 & Jalore & 10640 & 5 & $|8,30,15|$ & 8 & 172 \\
\hline 7 & Jodhpur & 22850 & 12 & $36,85,681$ & 16 & 161 \\
\hline 8 & Jaisalmer & 38401 & 20 & $6,72,008$ & 3 & 17 \\
\hline 9 & Nagaur & 17718 & 9 & $33,09,234$ & 15 & 187 \\
\hline 10 & Pali & 12387 & 6 & $20,38,533$ & 9 & 165 \\
\hline total & 10 & |9509| & 100 & $222,98,144$ & 100 & 114 \\
\hline
\end{tabular}

Causes of low rainfall in the arid region of west Rajasthan

A heat low over Pakistan and West Rajasthan region develops from April onwards and becomes intense in June- July and persists there till about September end. Under its influence southwesterly moist winds generally prevail over Rajasthan during the monsoon months. But compared to other parts of the country the rainfall of West Rajasthan is the lowest. The main reason for this is that the depth of monsoon current is quite shallow limited to a kilometer or so. This is over run by dry air from the north circulating anti-cyclonically between 1.5 and $4 \mathrm{~km}$ and inhibiting formation of precipitation. ${ }^{1}$ The rainfall in the monsoon months over West Rajasthan mostly occurs in association with the monsoon depressions and low pressure areas which move up to parts of Rajasthan from the Bay of Bengal and the Arabian sea. According to ${ }^{8}$ the number of depressions which moved across Rajasthan during the period 1891-1970 was of the order of 145 of which about 129 occurred during the month of July to September. Of the 145 disturbances, 114 had their origin from the Bay of Bengal, 9 moved from the Arabian Sea and the remaining were lows. The activity of the monsoon therefore is not felt over Rajasthan unless a low pressure area or depression moves towards it from east. In most cases, it was observed that when a monsoon depression/low is near northwest Madhya Pradesh, Rajasthan starts getting rainfall which increases in intensity as it approaches Rajasthan. When a low or depression moves west- north-westwards through Rajasthan, well distributed rain occurs over a large part of Rajasthan including West Rajasthan. 


\section{Rainfall over west Rajasthan}

\section{Rainfall over different districts of west Rajasthan}

Like other parts of the country, the southwest monsoon is the main feature in the hydrometeorology of West Rajasthan. Table 2 gives the averages of seasonal and annual rainfall and rainy days for the 10 districts of West Rajasthan. In West Rajasthan the average annual rainfall ranges from $16.5 \mathrm{~cm}$ in Jaisalmer district to $49.2 \mathrm{~cm}$ in Pali district. As a matter of fact Jaisalmer which is a sandy desert area is the district with the lowest rainfall in the whole of India. The annual rainfall is higher in the districts of Jalore, Pali and Nagaur with $49.2 \mathrm{~cm}$ in Pali. The number of rainy days during the monsoon period from June to September over West Rajasthan varies from 8 in Jaisalmer district to 23 in Pali district. About $90 \%$ of the rain occurs during the monsoon season and the balance of $10 \%$ occurring due to western disturbances and thunderstorms. A vast area extending from Barmer in the southwest to Ganganadar in the northeast has annual rainfall of less than $30 \mathrm{~cm}$. This region is not normally exposed to moist air masses for extended period and rainfall is irregular averaging only 2 or 3 days per month. However, in favorable synoptic situations, which infrequently occur over extensive part of the region, up to $40 \mathrm{~cm}$ of rain may fall within a few days resulting in flooding.

\section{Rainfall over West Rajasthan as a whole}

The average monthly and annual rainfall, the number of rainy days and the coefficient of variability worked out on the basis of rainfall data for the 124 year period (1871-1994) of West Rajasthan as a whole are given in Table 3. This table shows that the average annual rainfall of West Rajasthan as a whole is about $29.5 \mathrm{~cm}$ with a coefficient of variability of $37 \%$. The region receives about $87 \%$ of the annual rainfall during the southwest monsoon season within 14 rainy days which not only nourishes the kharif crops but enriches all sources of water bodies. The bulk of the remaining $13 \%$ occurs mostly in the winter months (December- February) in association with western disturbances. Most of the annual rainfall is concentrated in the two months of July and August within 10 rainy days. Table 3 also gives the monthly variability of rainfall. The coefficient of variation for West Rajasthan during the monsoon months varies from 53 to $90 \%$. Variability during the non monsoon months is very high indicating the erratic nature of the rainfall during these months. Among the four monsoon months, the lowest variability of rainfall of $53 \%$ is in July, when the monsoon is at its peak. The annual rainfall map of Rajasthan is given in Figure 2. The annual rainfall in West Rajasthan varies significantly and ranges from $40 \mathrm{~cm}$ in the southeast extremity to less than $15 \mathrm{~cm}$ in the northwest part of Jaisalmer.

Table 2 Average seasonal and annual rainfall $(\mathrm{cm})$ \& rainy days in the districts of west Rajasthan

\begin{tabular}{|c|c|c|c|c|c|c|c|}
\hline Sr.no & District & & $\begin{array}{l}\text { Winter (Dec- } \\
\text { Feb) }\end{array}$ & $\begin{array}{l}\text { Summer (Mar- } \\
\text { May) }\end{array}$ & $\begin{array}{l}\text { Monsoon (June- } \\
\text { Sept) }\end{array}$ & $\begin{array}{l}\text { Post monsoon (Oct- } \\
\text { Nov) }\end{array}$ & Annual \\
\hline \multirow[t]{2}{*}{1} & Barmer & $\mathrm{RF}$ & 0.8 & 1.2 & 25.4 & 0.4 & 27.8 \\
\hline & & RD & 0.6 & 0.8 & II.I & 0.2 & 12.7 \\
\hline \multirow[t]{2}{*}{2} & Bikaner & RF & 1.4 & 1.8 & 22.6 & 0.63 & 26.4 \\
\hline & & RD & 1.4 & 1.8 & 13.1 & 0.3 & 16.5 \\
\hline \multirow[t]{2}{*}{3} & Churu & $\mathrm{RF}$ & 1.8 & 2 & 28.1 & 0.7 & 32.6 \\
\hline & & RD & 1.9 & 2 & 15.1 & 0.4 & 19.4 \\
\hline \multirow[t]{2}{*}{4} & Ganganagar & $\mathrm{RF}$ & 2.3 & 1.6 & 18.2 & 0.2 & 22.3 \\
\hline & & RD & 2.4 & 1.7 & 10.1 & 0.2 & 14.4 \\
\hline \multirow[t]{2}{*}{5} & Hanumangarh & $\mathrm{RF}$ & 2.5 & 2.1 & 25.1 & 0.6 & 30.3 \\
\hline & & RD & 2.4 & 2.2 & 13 & 0.3 & 17.9 \\
\hline \multirow[t]{2}{*}{6} & Jaisalmer & $\mathrm{RF}$ & 0.7 & 0.7 & 15 & 0.1 & 16.5 \\
\hline & & RD & 0.5 & 0.6 & 6.6 & 0 & 7.7 \\
\hline \multirow[t]{2}{*}{7} & Jalore & $\mathrm{RF}$ & 0.9 & 0.9 & 39.7 & 0.7 & 42.2 \\
\hline & & RD & 0.7 & 0.7 & 16.9 & 0.4 & 18.7 \\
\hline \multirow[t]{2}{*}{8} & Jodhpur & $\mathrm{RF}$ & I.I. & 1.4 & 28.9 & 0.5 & 31.9 \\
\hline & & RD & 1.1 & 1.4 & 14.7 & 0.4 & 17.6 \\
\hline \multirow[t]{2}{*}{9} & Nagaur & RF & 1.7 & 2.1 & 34.5 & 0.7 & 39 \\
\hline & & RD & 1.5 & 2 & 18.1 & 0.5 & 22.1 \\
\hline \multirow[t]{2}{*}{10} & Pali & $\mathrm{RF}$ & I.I & 1.5 & 45.9 & 0.7 & 49.2 \\
\hline & & RD & 1 & 1.3 & 19.7 & 0.6 & 22.6 \\
\hline
\end{tabular}

RF- Rainfall in $\mathrm{cm}$ and RD- Rainy days (rainfall of $2.5 \mathrm{~mm}$ or more) 
Table 3 Average monthly and annual rainfall (cm) of west Rajasthan (1871-1994)

\begin{tabular}{|c|c|c|c|c|c|c|c|c|c|c|c|c|c|}
\hline Months & Jan & Feb & Mar & Apr & May & June & Jul & Aug & Sept & Oct & Nov & Dec & Annual \\
\hline Rainfall $(\mathrm{cm})$ & 0.5 & 0.6 & 0.4 & 0.3 & I.I & 2.9 & 9.2 & 9.5 & 4 & 0.5 & 0.2 & 0.3 & 29.5 \\
\hline$\%$ of annual & 1.7 & 2 & 1.4 & I & 3.7 & 9.8 & 31.2 & 32.2 & 13.6 & 1.7 & 0.7 & 1 & 100 \\
\hline CV (\%) & 135 & 155 & 195 & 211 & 114 & 90 & 53 & 70 & 99 & 205 & 261 & 199 & 37 \\
\hline Rainy days & 0.5 & 0.6 & 0.4 & 0.3 & 0.7 & 1.8 & 4.9 & 4.9 & 2.1 & 0.3 & 0.1 & 0.2 & 16.8 \\
\hline
\end{tabular}

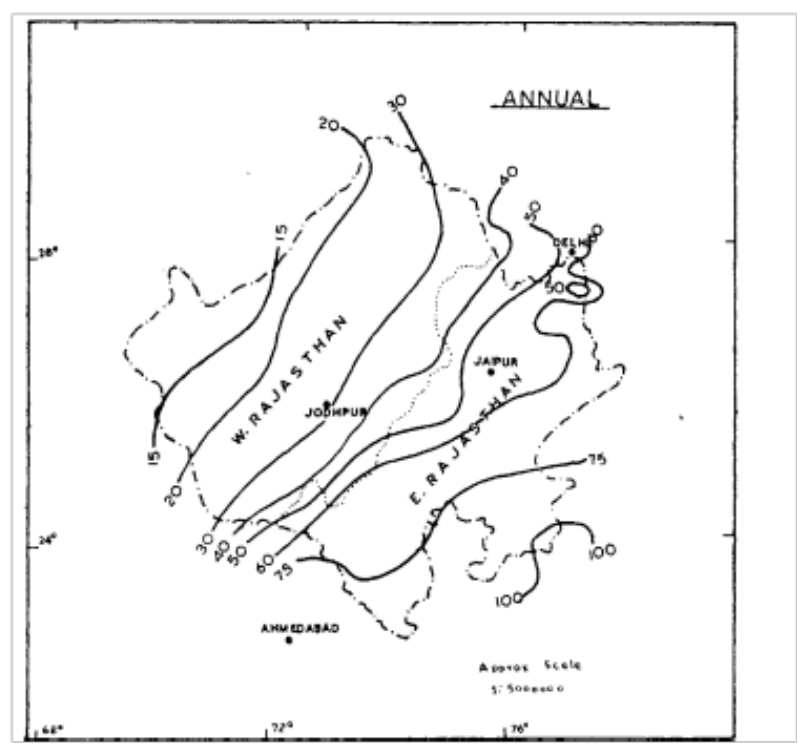

Figure 2 Annual rainfall (cm) map.

\section{Inter annual variation of rainfall}

Being located in the western most part of India, West Rajasthan comes uunder the influence of monsoon currents after the monsoon has advanced over the rest of the country. The normal dates of the advance of the monsoon over West Rajasthan are 2 July in the southern parts and 8 July in the extreme western parts. The monsoon begins to withdraw by the first week of September and the withdrawal is normally completed by the middle of September. The late commencement of monsoon, breaks in monsoon and its early withdrawal cause variability in rainfall from year to year. This variability is present in the records of annual and seasonal rainfall totals of West Rajasthan. In order to show the variation of rainfall over West Rajasthan as a whole, average annual rainfalls for the 124-year period (1871-1994) are given in Table 4. From this table, it can be seen that rainfall is not the same every year over West Rajasthan. The total annual rainfall varies significantly from year to year. The highest and lowest annual rainfalls over the period $1871-1994$ were $72.3 \mathrm{~cm}$ in 1917 and $3.7 \mathrm{~cm}$ in 1918 the next year and the $75 \%$ dependable rainfall is $22.5 \mathrm{~cm}$. Moreover, in the $8,17 \& 54$ years in the 124 years, the total annual rainfall exceeded $50.0 \mathrm{~cm}, 40.0 \mathrm{~cm} \& 30.0 \mathrm{~cm}$ respectively. There were years during which heavy rainfall resulted in the formation of runoff water in the rivers.

The general features of the frequency distribution of annual rainfall for the 124-year period (1871-1994) are shown in Figure 3. The shape of the frequency distribution is said to be skewed because Figure 3 Annual rainfall distribution. frequencies are not symmetrically distributed about the mean. The distribution is skewed to the right or positively skewed which shows larger frequency of relatively low values and a few extremely high values. In such a distribution the modal value is generally smaller than the median value which in turn is smaller than the mean value. The lack of symmetry of a distribution can best be studied by computing the coefficient of skewness (k) which is defined as follows:

$$
\text { Skewness }(k)=(\text { mean }- \text { mode }) / \text { standard deviation }(1)
$$

For $\mathrm{k}=0$, the distribution is symmetrical; for $\mathrm{k}>0$ the distribution is skewed to the right; and for $\mathrm{k}<0$ the distribution is skewed to the left. Based on the annual rainfall data of West Rajasthan the value of skewness is computed as +0.18 . $^{9}$

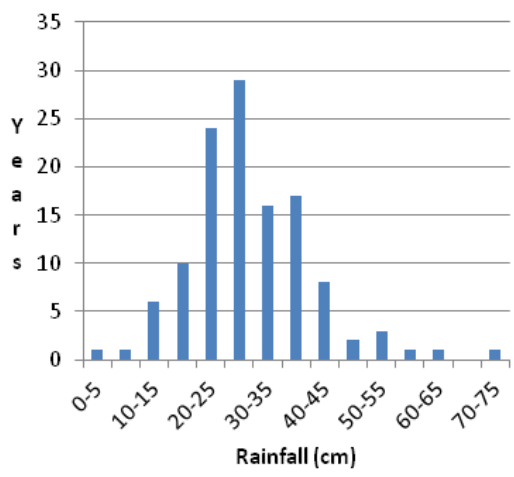


Table 4 Yearly rainfalls $(\mathrm{cm})$ over west Rajasthan $(1871-1994),{ }^{10}($ average annual rainfall $=29.5 \mathrm{~cm})$

\begin{tabular}{lllllllllll}
\hline Year & $\mathbf{0}$ & $\mathbf{I}$ & $\mathbf{2}$ & $\mathbf{3}$ & $\mathbf{4}$ & $\mathbf{5}$ & $\mathbf{6}$ & $\mathbf{7}$ & $\mathbf{8}$ & $\mathbf{9}$ \\
\hline 1870 & - & 33.4 & 30.6 & 34.6 & 25.4 & 33.8 & 36.7 & 17.4 & 35.2 & 36 \\
1880 & 26.6 & 34.9 & 33.8 & 23.8 & 38.2 & 20.2 & 27.7 & 17.4 & 25.1 & 29.1 \\
1890 & 24.9 & 20.9 & 43.5 & 54 & 37.4 & 22.5 & 26.6 & 35.2 & 25.4 & 5.4 \\
1900 & 30.5 & 15.6 & 20 & 29.7 & 22.1 & 11 & 29.8 & 38.6 & 61 & 44.1 \\
1910 & 30.4 & 14 & 27.6 & 22.1 & 29.3 & 15,2 & 41.9 & 72.3 & 3.7 & 28.9 \\
1920 & 25.9 & 23 & 22 & 28.6 & 26.8 & 13.4 & 42.6 & 31.7 & 27.3 & 30.6 \\
1930 & 20.9 & 37.5 & 26.4 & 36.6 & 31.1 & 24 & 24.9 & 29.1 & 19.3 & 12.6 \\
1940 & 31.3 & 21.2 & 36.5 & 25.9 & 59.2 & 36.2 & 19.7 & 29.4 & 23.5 & 25 \\
1950 & 31.1 & 21.8 & 23.3 & 37.2 & 28 & 40.9 & 40.5 & 25.6 & 28.7 & 36.6 \\
1960 & 22.6 & 40.9 & 29 & 17.5 & 33.9 & 22.5 & 26.3 & 37.4 & 11.6 & 10.3 \\
1970 & 34.9 & 23.2 & 21 & 42.4 & 18.5 & 51.6 & 45.6 & 36.9 & 39 & 38.1 \\
1980 & 21.4 & 28.1 & 35.1 & 49.6 & 21.7 & 26.1 & 20.2 & 16 & 29.3 & 27.9 \\
1990 & 53.1 & 17.8 & 54.1 & 32.5 & 36.9 & & & & & \\
\hline
\end{tabular}

Incidence of heavy rainfall in the districts of west Rajasthan

Although the average annual rainfall of West Rajasthan is quite low there are some fascinating aspects of the heavy rains seen in the desert area of West Rajasthan. An examination of daily rainfall data of all stations in this region has shown that associated with certain meteorological situations like monsoon depressions or lows when rainfall of the order of 25 to $50 \mathrm{~cm}$ in one day has occurred at individual stations in the past. Particularly intriguing are that at some stations more than their average annual amount was recorded in a single day (see Table 5 for more such surprises). Chotan recorded
$35.6 \mathrm{~cm}$ of rainfall on 26 August, 1944 as against the annual average rainfall of $23.9 \mathrm{~cm}$. Balotra recorded $33.7 \mathrm{~cm}$ of rainfall on $26 \mathrm{July}$, 1995 as against the annual average rainfall of $29.4 \mathrm{~cm}$. Shergarh recorded $29.9 \mathrm{~cm}$ on 2 September, 1908 against the annual average of $26.5 \mathrm{~cm}$. Bap received $26.7 \mathrm{~cm}$ of rainfall on 8 August, 1933 as against the annual average of $18.4 \mathrm{~cm}$. Heavy falls of rain exceeding $25 \mathrm{~cm}$ in one day are not therefore uncommon in this region. These are comparable with similar figures at some of the normally semi arid and sub humid stations in the country. Table 5 gives the heaviest one day rainfalls recorded at stations in the various desert districts of West Rajasthan during the period 1890 to 2007.

Table 5 Highest daily rainfalls $(\mathrm{cm})$ in the arid districts of west Rajasthan ${ }^{11}$

\begin{tabular}{|c|c|c|c|c|c|c|c|c|c|}
\hline District & Station & $\begin{array}{l}\text { Highest } \\
\text { rainfall }(\mathrm{cm})\end{array}$ & $\begin{array}{l}\text { Date } \\
\text { \&Year }\end{array}$ & $\begin{array}{l}\text { Annual } \\
\text { rainfall } \\
(\mathrm{cm})\end{array}$ & District & Station & $\begin{array}{l}\text { Highest } \\
\text { rainfall }(\mathrm{cm})\end{array}$ & $\begin{array}{l}\text { Date \& } \\
\text { year }\end{array}$ & $\begin{array}{l}\text { Annual } \\
\text { rainfall } \\
(\mathrm{cm})\end{array}$ \\
\hline \multirow[t]{7}{*}{ Barmer } & Chotan & 35.6 & 26.8 .1944 & 23.9 & Jalore & Bhinmal & 28.4 & $|4.8 .194|$ & 47.8 \\
\hline & Barmer & 25.6 & 13.8.1944 & 31.4 & & Jalore & 26.8 & 5.7 .1990 & 36.3 \\
\hline & Sheo & 20.3 & 28.7 .1929 & 20.8 & Jodhpur & Shergarh & 29.9 & 2.9 .1908 & 26.5 \\
\hline & Pachpadra & 37 & 12.8 .1992 & 27 & & Phalodi & 22.5 & 12.7 .1964 & 23.6 \\
\hline & Balotra & 33.7 & 26.7 .1995 & 29.4 & & Jodhpur & 21.6 & 12.91924 & 36.6 \\
\hline & Gudha & 27 & 6.8 .1990 & 26.6 & & Bilara & 30 & 31.7 .1999 & 43.5 \\
\hline & Siwana & 20.5 & 18.8 .1973 & 34.4 & Nagaur & Parbatsar & 30.7 & 24.7.1929 & 38.9 \\
\hline Bikaner & Palana & 26.6 & 7.8 .1933 & 28.7 & & Nagore & 24.2 & 28.8 .1953 & 31 \\
\hline \multirow[t]{2}{*}{ Churu } & Sardarshar & 22.6 & 9.7196 & 28.1 & & Mertacity & 27.9 & 16.7 .1943 & 41.9 \\
\hline & Sujangarh & 20.9 & 22.7 .1957 & 37.2 & Pali & Desuri & 38.1 & 31.7 .1952 & 62.6 \\
\hline Ganganagar & Ganganagar & 25.2 & 31.8 .1928 & 30.3 & & Bali & 35 & 5.7 .1990 & 56.4 \\
\hline Jaisalmer & Bap & 26.7 & 8.8 .1933 & 18.4 & & Jaitaran & 22.6 & 17.7.1979 & 37.8 \\
\hline \multirow[t]{2}{*}{ Jalore } & Sanchor & 51.2 & 16.9 .1893 & 38.1 & & Sojat & 30.5 & 6.7 .1908 & 47.2 \\
\hline & Jaswantpura & 32.5 & 6.8 .1990 & 47.1 & & Pali & 35.7 & 5.7.2007 & 41.1 \\
\hline
\end{tabular}




\section{Severe rainstorms over west Rajasthan}

Flood producing rainstorms are rare due to poor rainfall in West Rajasthan but unusually high quantum of rain from severe rainstorms associated with lows or the cyclonic storms coming from the Bay of Bengal as discussed in section 4 can result in floods in West Rajasthan. Daily rainfalls for the period 1871-2010 were surveyed to determine the severe rainstorms that produced the greatest areal rainfalls over the West Rajasthan. This yielded the following list of sever rainstorms.

a. 30-31 July 1952 with centre at Desuri $\left(24^{\circ} 46^{\prime} \mathrm{N}, 75^{\circ} 53^{\prime} \mathrm{E}\right)$

b. 17-19 August 1973 with centre at Siwana $\left(25^{\circ} 39^{\prime} \mathrm{N}, 72^{\circ} 25^{\prime}\right.$ E)

\section{c. 25-27 July 1995 with centre at Balotra}

Of these, the August 17-19, 1973 rainstorm gave the greatest areal rainfalls over West Rajasthan. In a sense, this was considered for analysis. ${ }^{10}$

\section{Rainstorm of august I 973 over west Rajasthan}

The 1973 rainstorm was associated with the movement of a low pressure area from the central Uttar Pradesh which strengthened and became well marked on $14^{\text {th }}$ and $15^{\text {th }}$ August during its movement over central Rajasthan. It concentrated into a depression near Jaisalmer on $17^{\text {th }}$ August and after recurving in a south-easterly direction, deepened on $18^{\text {th }}$ August but weakened again into low pressure area over east Rajasthan on $19^{\text {th }}$ August and finally merged with the seasonal trough. During this period a western disturbance also moved across the extreme north of the country between 16-18 August. In association with both these systems, vigorous monsoon conditions prevailed all over Rajasthan. This rainstorm was quite unique as it caused widespread heavy rainfall over entire Rajasthan between 13-19 August. It was found that the storm gave the greatest areal depths of rainfall over east Rajasthan from 13 to 15 August and West Rajasthan recorded the greatest rain depths from 17-19 August. Some stations in West Rajasthan recorded in one day rainfall amounts exceeding their respective mean annual rainfall. Jaisalmer which is situated in the heart of the desert recorded $20 \mathrm{~cm}$ of rainfall on 16 August while its mean annual rainfall is about $18 \mathrm{~cm}$. Other stations like Jalore and Barmer recorded 17 and $23 \mathrm{cms}$ respectively on 17 and 18 August. The isohyetal map of this rainstorm for the period 17-19 August is shown in Figure 4. The water potential generated by this rainstorm for each day of the rainspell over West Rajasthan is given in Table $6 .{ }^{11}$

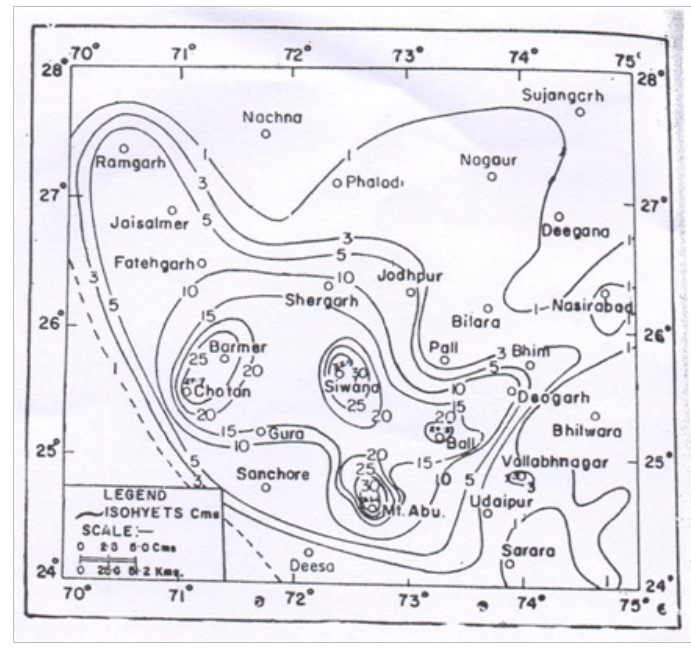

Figure 4 Isohyetal map of 17-19 August 1973 rainstorm over west Rajasthan.
Table 6 Water potential generated by the August 1973 rainstorm over west Rajasthan

\begin{tabular}{llll} 
Date & $\begin{array}{l}\text { 17 August } \\
1973\end{array}$ & $\begin{array}{l}\text { I8 August } \\
1973\end{array}$ & 19 August 1973 \\
\hline Average rainfall $(\mathrm{cm})$ & 3.2 & 5.4 & 4.1 \\
Area covered $\left(\mathrm{km}^{2}\right)$ & 73012 & 7472 I & 6708 I \\
Water Potential (million $\left.\mathrm{m}^{3}\right)$ & 2336 & 4035 & 2750
\end{tabular}

\section{Rainfall fluctuations in west Rajasthan}

\section{Droughts}

A characteristic of the desert areas is the occurrence of frequent droughts that make it difficult to meet the water demands for the various uses. Drought in general terms refers to an acute water shortage. This is mainly due to rainfall deficiency but with other parameters contributing to the actual water availability. The best single measure of water availability in the desert of West Rajasthan is rainfall although parameters such as evaporation and soil moisture are significant. Droughts have severe economic effects in West Rajasthan and there have been major droughts which affected agricultural production. The droughts of 1968 and 1969 that occurred one after another were probably most disastrous in their effects on economy. It is, therefore, of crucial importance to study the occurrence of droughts in West Rajasthan in terms of rainfall deficiency on account of failure of rains. For India, the India Meteorological Department ${ }^{12}$ has defined that a drought year at certain station or region occurs when the year's rainfall is less than $75 \%$ of the normal rainfall value (deficiency of rainfall exceeds $25 \%$ of region's normal rainfall). The drought is further classified as moderate when year's rainfall is between $75 \%$ and $50 \%$ of the normal value (deficiency of rainfall between $25 \&$ $50 \%$ ) and severe drought when the year's rainfall is less than $50 \%$ of the normal value (deficiency exceeds $50 \%$ of the normal rainfall). On the basis of this criterion, the rainfall of each year in West Rajasthan was classified as moderate or severe during the period 1871- 1994. The moderate and severe drought years are listed in Table 7.

Table 7 Drought years in west Rajasthan during 1871-1994, (Source: Table 4)

\begin{tabular}{|c|c|}
\hline $\begin{array}{l}\text { Moderate drought years (rainfall } \\
\text { deficiency of } 25-50 \% \text { ) }\end{array}$ & $\begin{array}{l}\text { Severe droughts years } \\
\text { (rainfall deficiency } \\
\text { exceeds }(50 \%)\end{array}$ \\
\hline $\begin{array}{l}\text { I877, I885, I887, I89I, I90I, I902, I904, } \\
1913,1915,1922,1930,1938,1941,1946, \\
1951,1963,1972,1974,1980,1984,1986, \\
1987,1991\end{array}$ & $\begin{array}{l}1899,1905,1911,1918 \\
1925,1939,1968,1969\end{array}$ \\
\hline Total $=23$ & Total $=8$ \\
\hline
\end{tabular}

Table 7 shows that in West Rajasthan 31 drought years have occurred during the 124-year period (1871-1994) of which 8 were severe drought years. This indicates that after every 4 years of good rainfall cycle, one or two moderate or severe drought years follow. Moreover, five times two consecutive drought years one after another (1901-1902; 1904-1905; 1938-1939; 1968-1969 and 1986-1987) with low rainfalls have also occurred. The occurrences of droughts one after another were worrisome periods. However, in West Rajasthan, drought years occur at irregular intervals.

\section{Floods}

Widespread flood rainfall may occur anywhere in West Rajasthan associated with an unusual meteorological situation. For example, a low pressure area in August 1973 produced flood rainfall over West 
Rajasthan and caused loss of life and property. It is more important in the context of desert hydrology to study the occurrence of flood rainfall in West Rajasthan in terms of rainfall. The ${ }^{12}$ has defined flood as a situation occurring over an area in a year when the rainfall is more than $125 \%$ of the normal rainfall. If the rainfall is more than $125-150 \%$ of normal, it is called moderate flood rainfall and if rainfall is more than $150 \%$ of the normal, it is called severe flood rainfall. On the basis of this criterion, the rainfall of each year in West Rajasthan was classified as moderate or severe flood rainfall during the period 1871-1994. The years of moderate and severe flood rainfall are listed in Table 7. This table shows that 27 flood rainfall years have occurred during the 124 years and during these years the annual rainfall was in excess of 125 to $245 \%$ of normal rainfall. As such on an average one flood rainfall year can be expected to occur in 4 or 5 years. It is more interesting to see that 2, 2 and 1 times 2 (1916-1917; 1955-1956), 3 (1892-1894; 1907-1909), and 5 (1975-1979) consecutive flood rainfall years respectively with high amount of rainfalls have also occurred. Flood rains however, occur at irregular intervals in West Rajasthan.

\section{Probable maximum precipitation (PMP)}

It has been seen in section 7 that the maximum rainfall as high as $51 \mathrm{~cm}$ has been recorded in one day at a station in West Rajasthan. This magnitude of rainfall however, varies from place to place. It is of great importance to know the highest rainfall that is physically possible over a given station or an area. This is called the Probable maximum Precipitation (PMP) and according to ${ }^{13}$ is defined as the greatest depth of rainfall for a given duration that is physically possible for a given station or specified area. The main use of PMP is for the safe design of a variety of hydrological structures as also has a key role in flood plain management. The one-day PMP for stations in West Rajasthan were estimated from the frequency analysis of the annual maximum rainfall data of stations in West Rajasthan. ${ }^{14}$ Figure 5 shows the one day PMP for West Rajasthan. This figure shows that one-day PMP estimates vary from $30 \mathrm{~cm}$ to $90 \mathrm{~cm}$.

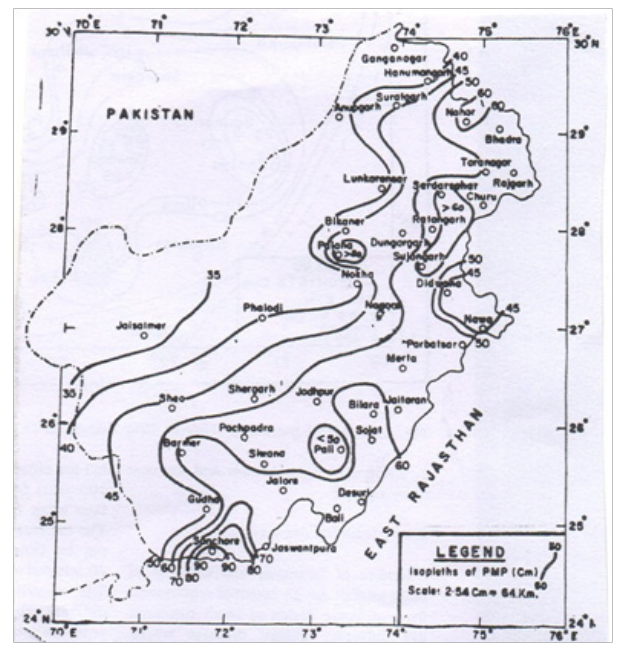

Figure 5 PMP (cm) for one-day over west Rajasthan.

\section{Conclusions}

Low rainfall and high temperature are the most visible characteristics of the desert climate. Despite harsh conditions, it is interesting to note that West Rajasthan is the most densely populated region in the world with a population density of 114 persons $/ \mathrm{km}^{2}$. Also, as compared to other desert regions of the world, West Rajasthan desert in India receives considerable amount of rainwater. There is a long felt realization that if we could reclaim this desert and make it more suitable for water availability for agriculture then there would be economic benefits for all concerned. An attractive feature of this paper is that it provides interesting information on climate and rainwater resources in West Rajasthan that is useful for sustainable availability of water and the alleviation of water scarcity.

\section{Acknowledgments}

None.

\section{Conflicts of interest}

The author declares that there are no conflicts of interest.

\section{References}

1. Pramanik SK. Hydrology of Rajasthan desert- rainfall, humidity \& evaporation. Symposium on Rajputana Desert. Bull Natn Inst Science India. 1952;223-236.

2. Jagannathan P, Raghavendra VK. Some aspects of hydrometeorology of Rajasthan. IJMG. 1966;17:197-203.

3. Koteswaram P. Meteorology and climatology of the Rajasthan desert Proc Indian natn Sci Acad. 1978;44(6):401-410.

4. Dhar ON, Rakhecha PR. Incidence of heavy rainfall in the Indian desert region. Proc of the Canberra Symposium. IAHS-AISH publ. 1979;128:33-42.

5. Rakhecha PR. Water Resources of Rajasthan. Natural \& Human resources of Rajasthan. Scientific Publications; Jodhpur. 1993;93-111.

6. Sikka DR. Desert Climate \& its Dynamics. Current Science. 1997;72(1):35-46.

7. Singh SS, Chauhan M, Kumawat RN. Rainfall Structure of Thar. The great Indian Desert Publ of Meteorological Centre, Jaipur, IMD, New Delhi. 2014;77.

8. Dhar ON, Rakhecha PR, Mandal BN. On some rainfall features of August 1973 rainstorm over Rajasthan. International hydrological decade, Newsletter. 1974;23-26:1-4.

9. Ministry of Information \& Broadcasting (MI \& B). India Reference annual. Govt of India publ. 2012.

10. Indian Institute of Tropical Meteorology (IITM). Monthly \& seasonal rainfall series for all India homogeneous regions and meteorological subdivisions: 1871-1994. IITM Research Report. 1995;113.

11. Rakhecha PR, Pisharoty PR. Heavy rainfall during monsoon season point and spatiall distribution. Current Sci. 1996;71(3):179-186.

12. India Meteorological Department (IMD). Rainfall and droughts in India. Report of the Drought Research Unit, Meteorological Dept. 1971.

13. World Meteorological Organization (WMO). Manual on estimation of probable maximum precipitation (PMP). WMO. 2009;291.

14. Rakhecha PR, Dhar ON. On some hydrometeorological aspects of heavy rainfall distribution over the principal arid zone of Rajasthan. Annals of Arid Zone. 1980;19(4):413-420. 